\title{
Pengaruh Motivasi Dan Kompensasi Terhadap Kinerja Karyawan Pada Kantor Cabang PT Bank Bri Syariah (Persero) Tbk. Palembang
}

\author{
Erfan Robyardi \\ Fakultas Ekonomi, Universitas PGRI Palembang
}

\begin{abstract}
ABSTRAK
Dalam melaksanakan kegiatan suatu instansi berlomba - lomba meningkatkan motivasi dan kompensasi karyawan maka peranan karyawan merupakan faktor penting, yaitu waktu, tenaga, dan kemampuan benar-benar harus dimanfaatkan secara optimal bagi kepentingan organisasi. Kinerja yang dihasilkan oleh orang karyawan mencerminkan keadaan pegawai yang bertanggung jawab terhadap tugas-tugas yang diberikan. Kinerja pegawai yang baik adalah kinerja yang optimal, yaitu kinerja yang sesuai standar organisasi yang mendukung tercapainya organisasi. Oleh karena itu upaya untuk meningkatkan kinerja pegawai merupakan tantangan bagi manajemen yang paling serius karena untuk mencapai tujuan dan kelangsungan organisasi tergantung pada kinerja karyawan yang ada didalamnya.

Metode analisis yang digunakan adalah analisis kuantitatif. Populasi dalam penelitian ini yaitu Bagian Mikro PT Bank Rakyat Indonesia Syariah (Persero) Tbk Palembang. Populasi berjumlah 35 responden pada Bagian Mikro PT Bank Rakyat Indonesia Syariah (Persero) Tbk Palembang.

Nilai koefisien determinasi $\left(\mathrm{R}^{2}\right)$ sebesar $86 \%$ yang artinya bahwa naik turunnya kinerja pegawai pada Bagian Mikro PT Bank Rakyat Indonesia Syariah (Persero) Tbk Palembang dapat dijelaskan oleh kontribusi motivasi dan kompensasi sebesar $86 \%$, sedangkan sisanya $24 \%$ dijelaskan oleh variabel lain yang tidak dimasukan dalam penelitian ini.

Terdapat pengaruh positif dan signifikan antara motivasi terhadap kinerja pegawai, diperoleh nilai thitung $=3,287=$ lebih besar dari nilai $t_{\text {tabel }}=2,037$. yang berarti $\mathrm{H}_{\mathrm{a}}$ diterima dan $\mathrm{H}_{\mathrm{o}}$ ditolak. Terdapat pengaruh positif dan signifikan antara kompensasi terhadap kinerja pegawai peroleh nilai thitung $=4,261$ lebih besar dari nilai $t_{\text {tabel }}=2,037$
\end{abstract}

Kata kunci: Motivasi, Kompensasi, dan Kinerja Karyawan

\section{Pendahuluan}

1.1. Latar Belakang Manusia merupakan unsur terpenting dan paling menentukan bagi kelancaran jalannya proses manajemen, maka hal-hal yang berhubungan dengan motivasi perlu mendapat perhatian yang sungguh-sungguh dari setiap pimpinan guna keberhasilan suatu organisasi. Apabila motivasi tersebut diiringi dengan kemampuan yang dimiliki karyawan dalam melaksanakan pekerjaannya, maka karyawan tersebut diharapkan dapat digerakkan, diorganisir, diarahkan, diawasi dan mengarahkan segala sumber daya yang dimilikinya untuk mengoptimalkan prestasi kerjanya.

Pemberian kompensasi pada setiap perusahaan dalam usaha meningkatkan semangat kerja karyawan berbeda baik bentuk maupun prosedur pembagiannya, tentunya sesuai dengan kemampuan perusahaan tersebut. Pemberian kompensasi sangat positif diterapkan dalam suatu perusahaan, dan dirancang tidak hanya untuk kepentingan karyawan namun juga untuk kepentingan perusahaan, antara lain bagi karyawan untuk 
mencegah agar tidak timbul mengenai karyawan dikemudian hari. Perusahaan harus dapat melakukan kebijakan kebijakan yang positif agar karyawan yang ada terdorong untuk mengembangkan kualitas dan kemampuannya, sehingga mereka mampu memenuhi tuntutan pekerjaan yang pada akhirnya tercapailah tujuan perusahaan tersebut.

Dalam melaksanakan kegiatan suatu instansi berlomba - lomba meningkatkan motivasi dan kompensasi karyawan maka peranan karyawan merupakan faktor penting, yaitu waktu, tenaga, dan kemampuan benarbenar harus dimanfaatkan secara optimal bagi kepentingan organisasi. Kinerja yang dihasilkan oleh orang karyawan mencerminkan keadaan pegawai yang bertanggung jawab terhadap tugas-tugas yang diberikan. Kinerja pegawai yang baik adalah kinerja yang optimal, yaitu kinerja yang sesuai standar organisasi yang mendukung tercapainya organisasi. Oleh karena itu upaya untuk meningkatkan kinerja pegawai merupakan tantangan bagi manajemen yang paling serius karena untuk mencapai tujuan dan kelangsungan organisasi tergantung pada kinerja pegawai yang ada didalamnya.

1.2. Identifikasi Masalah Adakah Pengaruh Motivasi dan Kompensasi terhadap Kinerja Karyawan Bagian Mikro PT Bank Rakyat Indonesia Syariah (Persero) Tbk Palembang?
1.3. Tujuan Penelitian

Tujuan penelitian ini
adalah untuk mengetahui
Motivasi dan Kompensasi
terhadap Kinerja Karyawan
Pada Bagian Mikro PT Bank
Rakyat Indonesia Syariah
(Persero) Tbk Palembang

1.4. Manfaat

1. Diharapkan dapat memberikan masukkan yang berupa saran kepada Bagian Mikro PT Bank Rakyat Indonesia Syariah (Persero) Tbk Palembang mengenai Motivasi dan Kompensasi terhadap Kinerja Karyawan

2. Sebagai bahan masukan hususnya dalam upaya memperhatikan motivasi dan kompensasi karyawan sehingga dapat meningkatkan kinerja karyawan

\section{Kajian Pustaka}

2.1 Pengertian Motivasi

Sutrisna dalam Mulyadi (2015 : 88) Motivasi adalah suatu faktor yang mendorong seseorang untuk melakukan aktivitas tertentu, oleh karena itu motivasi sering kali diartikan sebagai faktor pendorong perilaku seseorang setiap aktivitas yang dilakukan oleh sesorang pasti memiliki faktor pendorong aktivitas tertentu.

Mangkunegara (2005 :

61) menyatakan : "motivasi terbentuk dari sikap (attitude) karyawan dalam menghadapi situasi kerja di perusahaan (situation). Motivasi merupakan kondisi atau energi yang menggerakkan diri karyawan yang terarah atau tertuju untuk 
mencapai tujuan organisasi perusahaan. Sikap mental karyawan yang pro dan positif terhadap situasi kerja itulah yang memperkuat motivasi kerjanya untuk mencapai kinerja maksimal".

\section{Menurut Sunyoto} (2013:14) Indikator motivasi ada tujuh yaitu :

1. Promosi

Promosi adalah kemajuan seorang karyawan pada suatu tugas yang lebih baik, baik dipandang dari sudut tanggung jawab yang lebih berat, martabat atau status yang lebih tinggi, kecakapan yang lebih baik dan terutama tambahan pembayaran upah atau gaji.

2. Prestasi Kerja

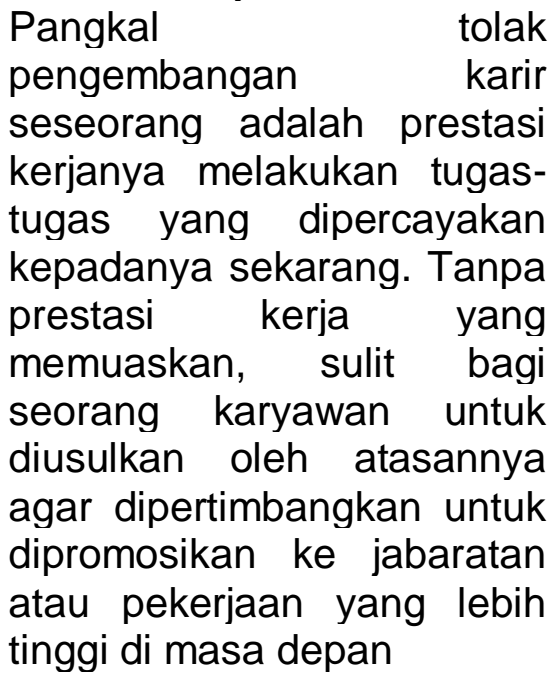

3. Pekerjaan Itu Sendiri

Tanggung jawab dalam mengembangkan karir terletak pada masing masing pekerja. Semua pihak seperti pimpinan, atasan langsung, kenalan dan para spesialis di bagian kepegawaian, hanya berperan memberikan bantuan, semua terserah pada karyawan yang bersangkutan, apakah akan memanfaatkan berbagai kesempatan mengembangkan diri atau tidak.

4. Penghargaan

Pemberian motivasi dengan melalui kebutuhan penghargaan, seperti penghargaan atas prestasinya, pengakuan atas keahlian dan sebagainya. Hal yang sangat diperlukan untuk memacu gairah kerja bagi para karyawan. Penghargaan di sini dapat merupakan tuntutan faktor manusiawi atas kebutuhan dan keinginan untuk menyelesaikan suatu tantangan yang harus dihadapi

5. Tanggung Jawab

Pertanggungjawaban atas tugas yang diberikan perusahaan kepada karyawan merupakan timbal balik atas kompensasi yang diterimanya. Pihak perusahaan memberikan apa yang diharapkan oleh para karyawan, namun di sisi lain para karyawan pun harus memberikan kontribusi penyelesaian pekerjaan dengan baik pula dan penuh dengan tanggung jawab sesuai dengan bidangnya masing - masing

6. Pengakuan

Pengakuan atas kemampuan dan keahlian bagi karyawan dalam suatu pekerjaan merupakan suatu kewajiban oleh perusahaan. Karena pengakuan tersebut merupakan suatu kewajiban oleh perusahaan. Karena pengakuan tersebut 
merupakan salah satu kompensasi yang harus diberikan oleh perusahaan kepada karyawan yang memang mempunyai suatu keahlian tertentu dan dapat melaksanakan pekerjaan dengan baik pula. Hal ini akan dapat mendorong para karyawan yang mempunyai kelebihan di bidangnya untuk berprestasi lebih baik lagi.

7. Keberhasilan Dalam Bekerja Keberhasilan dalam bekerja dapat memotivasi para karyawan untuk lebih bersemangat dalam melaksanakan tugas-tugas yang diberikan oleh perusahaan. Dengan keberhasilan tersebut setidaknya dapat memberikan rasa bangga dalam perasaan karyawan bahwa mereka telah mampu mempertanggungjawabkan apa yang menjadi tugas mereka.

2.2. Pengertian Kompensasi Menurut Mangkuprawira (2009:36) Kompensasi merupakan sesuatu yang diterima karyawan sebagai penukar dari kontribusi jasa mereka pada perusahaan. Jika dikelola dengan baik, kompensasi membantu perusahaan mencapai tujuan dan memperoleh, memelihara, dan menjaga karyawan dengan baik. Sebaliknya tanpa kompensasi yang cukup, karyawan yang ada sangat mungkin untuk meninggalkan perusahaan dan untuk melakukan penempatan kembali tidaklah mudah. Akibat dari ketidakpuasan dalam pembayaran bisa jadi akan mengurangi kinerja, meningkatkan keluhan-keluhan, penyebab mogok kerja, dan mengarah pada tindakantindakan fisik dan psikologis, seperti meningkatnya derajat ketidakhadiran dan perputaran karyawan, yang pada gilirannya akan meningkatkan kesehatan jiwa karyawan yang parah. Sebaliknya, jika terjadi kelebihan pembayaran, juga akan menyebabkan perusahaan dan individual berkurang daya kompetisinya dan menyebabkan kegelisahan, perasaan bersalah, dan suasana yang tidak nyaman dikalangan karyawan.

Menurut Husein Umar (2007:16) Indikator kompensasi adalah sebagai berikut.

1. Gaji Imbalan yang di berikan oleh pemberi kerja kepada pegawai, $\quad$ yang penerimaannya bersifat rutin dan tetap setiap bulan walaupun tidak masuk kerja maka gaji akan tetap diterima secara penuh.

2. Insentif

Penghargaan atau ganjaran yang diberikan untuk memotivasi para pekerja agar produktivitas kerjanya tinggi, sifatnya tidak tetap atau sewaktu-waktu

3. Bonus

Pembayaran sekaligus yang diberikan karena memenuhi sasaran kinerja.

4. Upah

Pembayaran yang diberikan kepada pegawai dengan lamanya jam kerja. 
5. Premi

premi adalah sesuatu yang diberikan sebagai hadiah atau derma atau sesuatu yang dibayarkan ekstra sebagai pendorong atau perancang atau sesuatu pembayaran tambahan di atas pembayaran normal

6. Pengobatan

Pengobatan di dalam kompensasi adalah pemberian jasa dalam penanggulan resiko yang dikaitkan dengan kesehatan karyawan.

7. Asuransi

Asuransi merupakan penanggulangan risiko atas kerugian, kehilangan manfaat dan tanggung jawab hukum kepada pihak ketiga yang timbul dari peristiwa yang tidak pasti

2.3. Pengertian Kinerja Menurut Mathis dan Jackson (2006:65) menyatakan bahwa kinerja pada dasarnya adalah apa yang dilakukan atau tidak dilakukan pegawai. Manajemen kinerja adalah keseluruhan kegiatan yang dilakukan untuk meningkatkan kinerja perusahaan atau organisasi, termasuk kinerja masing-masing individu dan kelompok kerja di perusahaan tersebut.

Menurut

Robbins (2006:260) ada enam indikator untuk mengukur kinerja karyawan secara individu adalah sebagai berikut :

1. Kualitas

Kualitas kerja diukur dari persepsi karyawan terhadap kualitas pekerjaan yang dihasilkan serta kesempurnaan tugas terhadap keterampilan dan kemampuan karyawan.

2. Kuantitas

Merupakan jumlah yang dihasilkan dinyatakan dalam istilah seperti jumlah unit, jumlah siklus aktivitas yang diselesaikan.

3. Ketepatan waktu

Merupakan tingkat aktivitas diselesaikan pada awal waktu yang dinyatakan, dilihat dari sudut koordinasi dengan hasil output serta memaksimalkan waktu yang tersedia untuk aktivitas lain.

4. Efektivitas

Merupakan tingkat penggunaan sumber daya organisasi (tenaga, uang, teknologi, bahan baku) dimaksimalkan dengan maksud menaikkan hasil dari setiap unit dalam penggunaan sumber daya.

5. Kemandirian

Merupakan tingkat seorang karyawan yang nantinya akan dapat menjalankan fungsi kerjanya Komitmen kerja. Merupakan suatu tingkat dimana karyawan mempunyai komitmen kerja dengan instansi dan tanggung jawab karyawan terhadap kantor.

\section{Metodologi Penelitian}

3.1. Variabel Penelitian

Menurut Sugiyono

(2015:39) Variabel penelitian adalah segala sesuatu yang berbentuk apa saja yang ditetapkan oleh peneliti untuk dipelajari sehingga diperoleh informasi tentang hal tersebut, kemudian ditarik kesimpulannya. 
Variable - variable yang digunakan Pada penelitian ini adalah sebagai berikut:

1. Variabel bebas (Variabel Independen )

Variabel bebas merupakan merupakan variabel yang mempengaruhi atau yang menjadi sebab perubahannya atau timbulnya variabel dependen (terikat). Varibel bebas (X) dalam penelitian ini adalah Kompensasi (X1)

2. Variabel terikat (Variabel Dependen)

Variabel terikat merupakan variabel yang dipengaruhi atau yang menjadi akibat, karena adanya variabel bebas. Variabel terikat (Y) dalam penelitian ini adalah Produktivitas Karyawan (Y).

3.2. Definisi Opersional Variabel

Definisi Operasional Variabel

\begin{tabular}{|c|c|c|c|c|}
\hline No & Variabel & Definisi & Indikator & Skala \\
\hline 1 & Motivasi(X1) & $\begin{array}{l}\text { Sutrisna dalam } r \text { Mulyadi } \\
\text { (2015 : 88) Motivasi adalah } \\
\text { suatu faktor yang } \\
\text { mendorong seseorang untuk } \\
\text { melakukan aktivitas tertentu, } \\
\text { oleh karena itu motivasi } \\
\text { sering kali diartikan sebagai } \\
\text { faktor pendorong perilaku } \\
\text { seseorang setiap aktivitas } \\
\text { yang dilakukan } \\
\text { sesorang pasti memiliki } \\
\text { faktor pendorong aktivitas } \\
\text { tertentu }\end{array}$ & $\begin{array}{l}\text { 1. Promosi } \\
\text { 2. Prestasi Kerja } \\
\text { 3. Pekerjaan itu } \\
\text { sendiri } \\
\text { 4. Penghargaan } \\
\text { 5. Tanggung Jawab } \\
\text { 6. Pengakuan } \\
\text { 7. Keberhasilan } \\
\text { dalam bekerja }\end{array}$ & Ordinal \\
\hline 2 & $\begin{array}{l}\text { Kompensasi } \\
\text { (X2) }\end{array}$ & $\begin{array}{l}\text { Menurut Mangku prawira } \\
(2009: 36) \quad \text { Kompensasi } \\
\text { merupakan sesuatu yang } \\
\text { diterima karyawan sebagai } \\
\text { penukar dari kontribusi jasa } \\
\text { mereka pada perusahaan. }\end{array}$ & $\begin{array}{l}\text { 1. Gaji } \\
\text { 2. Insentif } \\
\text { 3. Bonus } \\
\text { 4. Upah } \\
\text { 5. Premi } \\
\text { 6. Pengobatan } \\
\text { 7. Asuransi }\end{array}$ & Ordinal \\
\hline 3 & $\begin{array}{l}\text { Kinerja } \\
\text { Karyawan } \\
(\mathrm{Y})\end{array}$ & 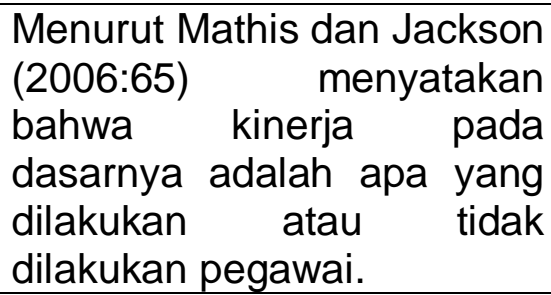 & $\begin{array}{l}\text { 1. Kualitas } \\
\text { 2. Kuantitas } \\
\text { 3. Ketepatan Waktu } \\
\text { 4. Efektivitas } \\
\text { 5. Kemandirian }\end{array}$ & Ordinal \\
\hline
\end{tabular}

3.3. Populasi dan Sample

Populasi dalam penelitian ini adalah seluruh karyawan pada Bagian Mikro PT Bank Rakyat Indonesia Syariah (Persero) Tbk Palembang.
Sampel Menurut Sugiyono (2014:91) sampel adalah bagian dari jumlah dan karakteristik yang dimiliki oleh populasi tersebut. Bila populasi besar, dan peneliti tidak mungkin 
mempelajari semua yang ada pada populasi, misalnya karena keterbatasan dana, tenaga dan waktu, maka peneliti dapat menggunakan sampel yang diambil dari populasi itu. Sampel yang diambil dalam penelitian ini adalah seluruh karyawan pada Bagian Mikro PT Bank Rakyat Indonesia Syariah (Persero) Tbk Palembang.

3.4. Teknik Pengumpulan Data

1. Kuisioner (angket)

Adalah teknik pengumpulan data yang dilakuakn dengan memberikan seperangkat pertanyaan yang di isi oleh responden.

2. Observasi

Observasi adalah suatu proses kompleks, tersusun dari berbagai proses biologis dan psikologis. Dua diantara yang terpenting adalah proses-proses pengamatan dan ingatan.
3.5. Teknik Analisis Data

1. Regresi Linier Sederhana

Pengaruh kompensasi terhadap produktivitas karyawan akan dianalisis dengan menggunakan regresi linier sederhana

$\mathrm{Y}=\mathrm{a}+\mathrm{bX}$

2. Koefisien Korelasi

Rumus Koefisien Korelasi

$$
\begin{aligned}
& r_{x y}= \\
& \frac{n\left(\sum x y\right)-\left(\sum x\right) \cdot\left(\sum y\right)}{\sqrt{\left\{n \sum x^{2}\right.}-\left(\sum x\right)^{2}\left\{n x y^{2}-\left(\sum y\right)^{2}\right\}}
\end{aligned}
$$

3. Koefisien Determinasi

Koefisien Determinasi Dicari Menggunakan rumus

$$
\mathrm{KP}=\mathrm{r}^{2} \times 100 \%
$$

4. Uji t

Rumus uji t dicari menggunakan rumus :

$$
t_{\text {hitung }}=\frac{r_{p} \sqrt{n-3}}{\sqrt{1-r p^{2}}}
$$

4. Hasil Penelitian dan Pembahasan

4.1. Hasil Uji Reliabilitas

Hasil Uji Reliabilitas Instrumen

\begin{tabular}{|c|l|c|c|}
\hline No & \multicolumn{1}{|c|}{ Variabel } & Cronbach Alpha & Keterangan \\
\hline 1. & Motivasi & 0,738 & Reliabel \\
\hline 2. & Kompensasi & 0,653 & Reliabel \\
\hline 3. & Kinerja Pegawai & 0,815 & Reliabel \\
\hline
\end{tabular}

Hasil uji reliabilitas tersebut menunjukkan bahwa semua variabel mempunyai Cronbach Alpha yang besar, yaitu lebih dari 0,60. Sehingga dapat disimpulkan bahwa item-item pengukur variabel dari kuesioner adalah reliabel yang berarti bahwa hubungan antara Motivasi (X1), Kompensasi (X2) Terhadap Kinerja Pegawai (Y) adalah kuat.

\subsection{Hasil Analisis Koefisien Determinasi $\left(R^{2}\right)$}

Analisis Koefisien Determinasi

Model Summaryb

\begin{tabular}{|l|c|r|r|r|}
\hline Model & $\mathrm{R}$ & $\begin{array}{c}\mathrm{R} \\
\text { Square }\end{array}$ & $\begin{array}{c}\text { Adjusted R } \\
\text { Square }\end{array}$ & $\begin{array}{c}\text { Std. Error of } \\
\text { the } \\
\text { Estimate }\end{array}$ \\
\hline 1 &, $855^{\mathrm{a}}$ &, 860 &, 844 & 1,821 \\
\hline
\end{tabular}


Berdasarkan tabel di atas dapat dijelaskan bahwa nilai koefisien determinasi $\left(\mathrm{R}^{2}\right)$ sebesar $86 \%$ yang artinya bahwa naik turunnya kinerja pegawai pada Bagian Mikro PT Bank Rakyat Indonesia Syariah (Persero) Tbk Palembang dapat dijelaskan oleh kontribusi motivasi dan kompensasi sebesar $86 \%$, sedangkan sisanya 24 $\%$ dijelaskan oleh variabel lain yang tidak dimasukan dalam penelitian ini.

4.3. Hasil Uji t

\section{Hasil Uji t}

\section{Coefficients $^{a}$}

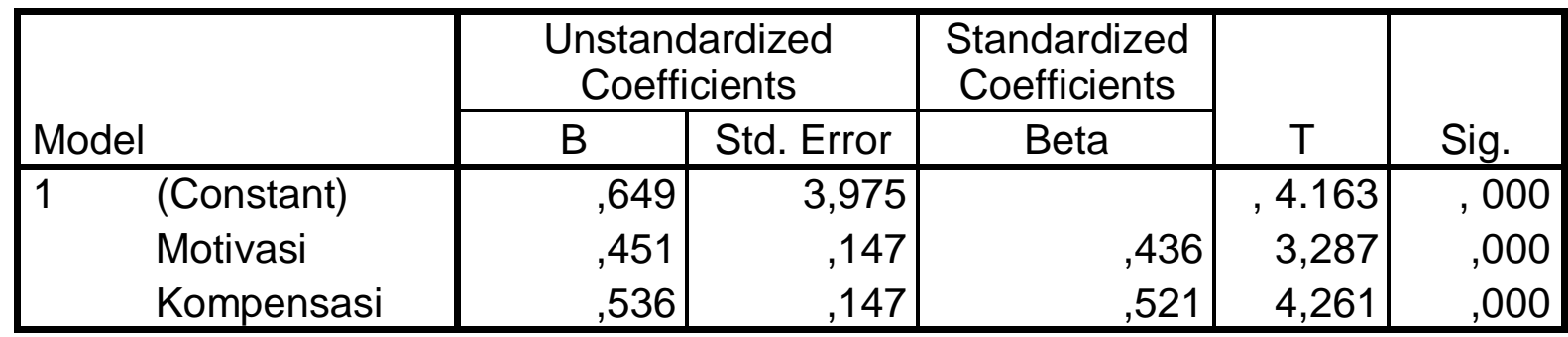

1. Hasil uji untuk variabel $X_{1}$ (motivasi) diperoleh nilai thitung $=$ 3,287 dengan taraf signifikansi 0,000 . Dengan menggunakan batas 0,05 didapat tabel sebesar $2,037(\mathrm{df}=\mathrm{n}-\mathrm{k}-1=35-2-1=32)$. Ini berarti $t_{\text {hitung }}>t_{\text {tabel }}=4,377>$ 2,037 yang berarti Ha diterima dan Ho ditolak. Dengan demikian berarti bahwa motivasi secara parsial berpengaruh signifikan terhadap kinerja pegawai.

2. Hasil uji untuk variabel $\mathrm{X}_{2}$ (kompensasi) diperoleh nilai thitung $=4,261$ dengan taraf signifikansi 0,002 . Dengan menggunakan batas 0,05 didapat tabel sebesar $2,037(\mathrm{df}=\mathrm{n}-\mathrm{k}-1=35-2-1=32)$. Ini berarti thitung $>$ ttabel $=3,385>$ 2,037 yang berarti $\mathrm{Ha}$ diterima dan Ho ditolak. Dengan demikian berarti bahwa secara parsial kompensasi berpengaruh signifikan tarhadap kinerja pegawai.

\section{Kesimpulan}

Berdasarkan hasil penelitian dan pembahasan yang telah di uraikan maka dapat disimpulkan bahwa Pengaruh Motivasi dan Kompensasi terhadap Kinerja Karyawan Bagian Mikro PT Bank Rakyat Indonesia Syariah (Persero) Tbk Palembang adalah sebagai berikut

a) Nilai koefisien determinasi $\left(R^{2}\right)$ sebesar $86 \%$ yang artinya bahwa naik turunnya kinerja pegawai pada Bagian Mikro PT Bank Rakyat Indonesia Syariah (Persero) Tbk Palembang dapat dijelaskan oleh kontribusi motivasi dan kompensasi sebesar $86 \%$, sedangkan sisanya $24 \%$ dijelaskan oleh variabel lain yang tidak dimasukan dalam penelitian ini.

b) Terdapat pengaruh positif dan signifikan antara motivasi terhadap kinerja pegawai, diperoleh nilai $t_{\text {hitung }}=3,287=$ lebih besar dari nilai tabel $=2,037$. yang berarti $\mathrm{H}_{\mathrm{a}}$ diterima dan $\mathrm{H}_{\mathrm{o}}$ ditolak.

c) Terdapat pengaruh positif dan signifikan antara kompensasi terhadap kinerja pegawai peroleh nilai thitung $=4,261$ lebih besar dari nilai $t_{\text {tabe }}=2,037$ 


\section{DAFTAR PUSTAKA}

Mulyadi. 2015. Manajemen Sumber Daya Manusia. Penerbit in Media Bogor.

Mankunegara, Anwar Prabu. Evaluasi Kinerja Sumber Daya Manusia. Bandung : Tiga Serangkai.

Sunyoto D. 2013. Manajemen Sumber Daya Manusia. Yogyakarta : Caps.

Mangkuprawira, Tb.S. 2004. Manajemen Sumber Daya Manusia Strategik. Jakarta : Ghalia Indonesia.
Umar Husein. 2007. Evaluasi Kinerja Perusahaan. Jakarta : Gramedia Pustaka Utama

Mathis, R.L. \& J.H. Jackson. 2006. Human Resource Management: Manajemen Sumber Daya Manusia. Terjemahan Dian Angelia. Jakarta: Salemba Empat.

Robbins, Stephen P., 2006. Perilaku Organisasi, PT Indeks, Kelompok Gramedia, Jakarta.

Sugiyono. 2015. Metode Penelitian Kuantitatif, Kualitatif dan R\&D. Bandung: Alfabeta. 